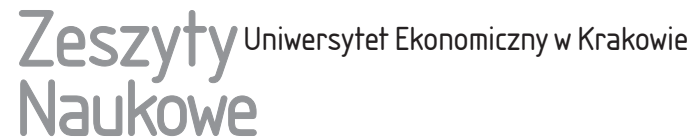

$4(976)$

ISSN 1898-6447

e-ISSN 2545-3238

Zesz. Nauk. UEK, 2018; $4(976): 59-72$

https://doi.org/10.15678/ZNUEK.2018.0976.0404

Katarzyna Czernek-Marszałek

\section{Znaczenie członkostwa w lokalnych organizacjach turystycznych dla budowania współpracy dwustronnej}

\section{Streszczenie}

Jednym ze sposobów konkurowania o turystów jest powoływanie na obszarach turystycznych lokalnych organizacji turystycznych (LOT). Ich celem, obok promocji turystycznej, jest tworzenie możliwości nawiązania dwustronnej współpracy gospodarczej między zrzeszonymi w nich podmiotami. W literaturze brakuje badań, w których wskazano by, czy przynależność do takich organizacji rzeczywiście służy budowaniu współpracy dwustronnej, a jeśli tak - to w jaki sposób, zaś jeśli nie - to dlaczego. Odpowiedź na to pytanie stanowi cel niniejszego artykułu. By go osiągnąć, wykorzystano metodę studium przypadku, którym była Wiślańska Organizacja Turystyczna (WOT), oraz wywiady półstrukturyzowane przeprowadzone w latach 2013 i 2014 z 48 członkami WOT. Wyniki badań pokazały, że WOT w niewielkim stopniu stanowi platformę umożliwiającą nawiązanie dwustronnej współpracy między członkami zrzeszonymi w tej organizacji. Wśród przyczyn tego stanu rzeczy wymienić można m.in. duże zróżnicowanie potrzeb i interesów członków organizacji, brak ich aktywnego uczestnictwa w spotkaniach LOT czy brak wyraźnie dostrzegalnych, mierzalnych korzyści funkcjonowania organizacji przy jednocześnie wyraźnych kosztach (składka członkowska). W artykule sformułowano także zalecenia, które mogą okazać się pomocne w zmianie tej sytuacji.

Katarzyna Czernek-Marszałek, Uniwersytet Ekonomiczny w Katowicach, Wydział Zarządzania, Katedra Teorii Zarządzania, ul. 1 Maja 50,40-287 Katowice, e-mail: katarzyna.czernek@ue. katowice.pl 
Słowa kluczowe: współpraca dwustronna, organizacja partnerska, lokalne organizacje turystyczne, turystyka.

Klasyfikacja JEL: M21, Z3.

\section{Wprowadzenie}

Od blisko 20 lat funkcjonują na polskich obszarach turystycznych liczne organizacje partnerskie. Ich celem jest między innymi promowanie oraz rozwój turystyki na danym obszarze. Wśród takich struktur ważne miejsce zajmują lokalne organizacje turystyczne (LOT). Do ich zadań należy, obok promocji turystycznej obszaru, tworzenie możliwości nawiązania współpracy gospodarczej (biznesowej) między podmiotami zrzeszonymi w tych organizacjach, w szczególności między prywatnymi przedsiębiorcami. Kooperacja taka ma służyć zarówno promocji obszaru reprezentowanego przez LOT, jak i rozwojowi indywidualnej działalności gospodarczej każdego z partnerów. Funkcjonowanie LOT, jako platformy budowania współpracy dwustronnej, nie jest jednak proste. Wynika to między innymi z faktu, że członkowie tych organizacji mają względem nich często inne oczekiwania aniżeli zarządzające nimi organy, różnie też postrzegają potrzebę kooperacji.

Celem niniejszego artykułu jest ustalenie, jakie znaczenie dla budowania współpracy dwustronnej ma przynależność do formalnych struktur partnerskich takich jak LOT. Założono, że w wypadku gdy badania wskażą, iż członkostwo w takich strukturach nie stymuluje współpracy dwustronnej, rozważania poszerzone zostaną o odpowiedź na pytanie o przyczyny takiego stanu rzeczy. Zagadnienie to nie było analizowane szerzej w dotychczasowej literaturze, stąd niniejsza praca ma służyć wypełnieniu tej luki badawczej. By osiągnąć założony cel, posłużono się przykładem Wiślańskiej Organizacji Turystycznej (WOT). Wykorzystano wywiady półstrukturyzowane przeprowadzone w latach 2013 i 2014 z 48 członkami WOT.

Na początku artykułu przedstawiono cele nawiązywania współpracy w formie organizacji partnerskich w turystyce, w szczególności lokalnych organizacji turystycznych. Wskazano także, że jednym ze sposobów oceny takich organizacji jest analiza jej roli jako platformy budowania współpracy dwustronnej między członkami LOT. Po omówieniu przyjętej metodyki zaprezentowano wyniki badań empirycznych prowadzonych w Wiśle. W pracy wskazano także na działania, jakie władze organizacji partnerskich w turystyce, w tym WOT, powinny podjąć, by członkostwo w takich organizacjach postrzegane było jako jedno z ważniejszych źródeł nawiązywania dwustronnej kooperacji gospodarczej i generowania $\mathrm{z}$ tego tytułu korzyści ekonomicznych dla danego przedsiębiorstwa. 


\section{Współpraca w formie lokalnych organizacji turystycznych a kooperacja dwustronna}

W regionach turystycznych funkcjonują obecnie różne formy współpracy - należą do nich m.in. porozumienia czy związki międzygminne, euroregiony, lokalne grupy działania, a także lokalne i regionalne organizacje turystyczne (odpowiednio LOT i ROT) (Fedyk i Morawski 2014, Rapacz 2005). Organizacje te zostały powołane pod koniec lat 90 . XX w. na mocy Ustawy z dnia 25 czerwca 1999 r. o Polskiej Organizacji Turystycznej (2018). Ich celem jest przede wszystkim promocja danego obszaru turystycznego. Zrzeszają one podmioty samorządu gminnego, powiatowego i wojewódzkiego, przedsiębiorstwa turystyczne, instytucje otoczenia rynkowego, a także wszystkie jednostki zainteresowane rozwojem turystyki. Ustawa zakłada, że członkami LOT i ROT mogą być osoby fizyczne i osoby prawne oraz że organizacje te mogą prowadzić działalność gospodarczą służącą realizacji ich celów i której przedmiot jest określony w ich statutach. LOT funkcjonują na poziomie gminnym i powiatowym, a ROT - na szczeblu województw. Jest to współpraca długookresowa, na podstawie której powstaje nowa organizacja partnerska, mająca osobowość prawną (funkcjonująca najczęściej w formie stowarzyszeń) (Czernek 2012, 2017). Obok promocji, do zadań regionalnych i lokalnych organizacji turystycznych należy także wspomaganie funkcjonowania i rozwoju informacji turystycznej, inicjowanie, opiniowanie i wspieranie planów rozwoju i modernizacji infrastruktury turystycznej oraz współpraca z Polską Organizacją Turystyczną (Ustawa z dnia 25 czerwca 1999 r.... 2018).

W dobie rosnącej konkurencji rynkowej działania LOT i ROT mają służyć osiąganiu przewagi konkurencyjnej regionów turystycznych (Crotts, Buhalis i March 2000, Collaboration... 2015, Merinero-Rodríguez i Pulido-Fernández 2016, Pechlaner, Volgger i Herntrei 2012). Funkcjonowanie tego typu organizacji wymaga dokonywania sukcesywnej oceny ich działalności. Z reguły odbywa się to poprzez analizę tego, czy i w jakim stopniu zostały osiągnięte założone przez nie cele (skuteczność) oraz jakim nakładem zasobów (efektywność) się to odbyło. W literaturze znajduje się wiele propozycji takiej oceny (np. Araujo i Bramwell 2002, Augustyn i Knowles 2000, Bramwell i Sharman 1999, Jamal i Getz 1999, Kozak i Baloglu 2011, March i Wilkinson 2009, Achieving... 2015).

Jak twierdzą B. Gray i D. Wood (1991, s. 13), większość sposobów oceny organizacji partnerskich bazuje jednak na ocenie finalnych rezultatów ich działalności, zaś doświadczenia wielu krajów, w których funkcjonują różne formy współpracy służącej rozwojowi turystyki w regionie, wskazują, że osiąganie końcowych celów tych organizacji jest często kwestią kilku, a czasem nawet kilkunastu lat. Dlatego B. Gray i D. Wood (1991) uznają, że taka współpraca powinna być oceniana z wykorzystaniem perspektywy dynamicznej i analizy nie tylko jej finalnych, 
ale także częściowych rezultatów. Jednym z nich jest budowanie nowych relacji między członkami organizacji, w tym stymulowanie między nimi dwustronnej współpracy biznesowej.

Niejednokrotnie rola takiej dwustronnej współpracy okazuje się ważniejsza dla partnerów aniżeli osiągnięcie celów, które przyświecały im, gdy przystępowali oni do organizacji partnerskiej. Współpraca taka odbywa się między dwoma autonomicznymi podmiotami, może mieć postać sformalizowaną (pisemną) lub niesformalizowaną (ustną), jej cele mogą być bardziej lub mniej złożone, przez co może ona mieć charakter kooperacji długoterminowej lub ad hoc. Dotyczyć może wielu obszarów działalności - od doradztwa zaczynając, przez wzajemne polecanie oferty partnera, korzystanie z jego oferty w zakresie obsługi własnych klientów, na wspólnych inwestycjach kończąc. Co ważne, ten rodzaj kooperacji, w porównaniu ze współpracą w formie członkostwa w organizacjach partnerskich, dostarcza stosunkowo szybkich i wyraźnych korzyści ekonomicznych, choćby w formie dodatkowych klientów (turystów) lub możliwości urozmaicenia własnej oferty, co przekłada się na bezpośrednie efekty finansowe (Czernek 2012).

Nawiązywanie kooperacji dwustronnej na obszarach turystycznych, jak wynika z badań, jest efektem przede wszystkim własnych, często prywatnych kontaktów między przedsiębiorcami (Czernek 2017). Można to tłumaczyć tzw. zakorzenieniem przedsiębiorców w sieci relacji społecznych (social embeddedness) (Granovetter 1985, Czernek 2017). W literaturze (Jack, Dodd i Anderson 2008) wskazuje się jednak, że także przynależność do wspólnych organizacji partnerskich, takich jak LOT, może stymulować budowanie współpracy dwustronnej między członkami tych organizacji. Przykładowo, kontakty bezpośrednie nawiązane w trakcie spotkań organizowanych przez organizacje partnerskie - np. poznanie się partnerów, zdobycie wiedzy na temat prowadzonej działalności gospodarczej i ewentualnych potrzeb z tym związanych, budowanie dialogu i zaufania między podmiotami itp. - może przyczynić się do nawiązywania współpracy dwustronnej, a to z kolei do bardziej skutecznego czy efektywnego funkcjonowania organizacji reprezentowanej przez danego przedsiębiorcę (Rahman i Korn 2014, Harrigan 1988). Dodatkowo, jak twierdzą N. Rahman i H.J. Korn (2014), organizacje partnerskie, których członków łączą stabilne relacje dwustronne, przetrwają dłużej niż te, w których relacje te są niestabilne i niepewne. By ustalić, czy i w jaki sposób przynależność do organizacji takich jak LOT służy budowaniu współpracy dwustronnej, autorka artykułu przeprowadziła badania empiryczne na przykładzie Wiślańskiej Organizacji Turystycznej. 


\section{Metodyka badań}

Wykorzystano badania jakościowe z zastosowaniem metody studium przypadku (case study) (Eisenhardt i Graebner 2007, Siggelkow 2007), który stanowiła Wiślańska Organizacja Turystyczna. Jest ona formą lokalnej organizacji turystycznej, została powołana w 2008 r. celem wspólnej promocji Wisły jako miejscowości atrakcyjnej turystycznie. Badania miały szerszy zasięg, ale służyły między innymi ocenie funkcjonowania WOT jako organizacji umożliwiającej przedsiębiorcom nawiązanie współpracy dwustronnej. Taki cel zresztą zapisany był w statucie organizacji.

Badania realizowano w latach 2013 i 2014ํํㄹ Przeprowadzono je wśród 48 spośród wszystkich 55 członków WOT. Narzędziem badawczym był kwestionariusz wywiadu półstrukturyzowanego z pytaniami otwartymi i zamkniętymi. Rozmówców wybierano zgodnie z zasadami doboru celowegom (Denzin i Lincoln 1994), korzystając z aktualnej listy członków WOT. Jeden z rozmówców reprezentował władze samorządowe miasta Wisły, zaś wszyscy pozostali byli przedstawicielami prywatnych przedsiębiorstw i odgrywali w nich rolę właścicieli lub menedżerów podejmujących decyzje dotyczące współpracy z innymi interesariuszami z terenu Wisły i regionu. Przedsiębiorstwa prywatne reprezentowały: obiekty noclegowe, gastronomiczne, transport, wyciągi narciarskie, atrakcje turystyczne, biura podróży itp.

Rozmówcy proszeni byli między innymi o udzielenie odpowiedzi na pytanie o to, czy i z którym z członków WOT, ale także innych podmiotów z terenu Wisły i regionu, współpracują w zakresie reprezentowanej w WOT działalności biznesowej. W momencie gdy deklarowali istnienie takiej współpracy, proszono o opisanie jej szerszego kontekstu, tj. wskazanie okoliczności nawiązania kooperacji - pytano, czy członkostwo w WOT było czynnikiem umożliwiającym nawiązanie współpracy dwustronnej, czy też nastąpiło to w innych okolicznościach. Proszono o opisanie, na czym polega współpraca, oraz o przedstawienie korzyści, jakie rozmówca dostrzega z kooperacji, lub wskazanie ewentualnych problemów z nią związanych. Materiał zgromadzony w ramach zadawania pytań otwartych został następnie poddany analizie jakościowej.

Wywiady były nagrywane, a następnie poddane transkrypcji. Obok analizy treści wywiadów przeprowadzono także analizę dodatkowych źródeł w postaci notatek terenowych sporządzonych w trakcie realizacji badań. Analiza danych

${ }^{1}$ Badania miały szeroki zasięg i pozwoliły na analizę różnych problemów zidentyfikowanych w wyniku ich przeprowadzenia. Do tej pory jednak nie wskazano, czy i jak przynależność do organizacji takich jak LOT służy budowaniu współpracy dwustronnej. Problematyka ta jest na tyle ciekawa i ważna, a przy tym ciągle aktualna, że czas, jaki upłynął od realizacji badań, wydaje się nie obniżać wartości merytorycznej wyciągniętych na ich podstawie wniosków. 
jakościowych opierała się na tzw. redukcji danych, ich generowaniu oraz weryfikacji (Miles i Huberman 1994). Redukcja danych polegała na dokonaniu transkrypcji wywiadów. Następnie na tej podstawie opracowano dokumenty (karty rozmówców) dla wszystkich 48 wywiadów oraz zakodowano cały materiał empiryczny. Generowanie danych opierało się na opracowaniu kodów odpowiadających dwóm możliwym źródłom nawiązywania współpracy: 1) dzięki wspólnej przynależności do WOT oraz 2) w ramach innych okoliczności. Z kolei weryfikacja danych polegała na analizie danych i ich skonfrontowaniu $\mathrm{z}$ istniejącą literaturą. Proces kodowania przeprowadzono z wykorzystaniem oprogramowania Atlas.ti. w wersji 7.0.

Wyniki badań wzbogacono cytatami z wywiadów, które uprawomocniają tekst oraz samego badacza (Kostera 2003) i które pozwalają przedstawić percepcję badanych bardziej realistycznie oraz dają czytelnikowi wrażenie osobistego doświadczania procesów i zjawisk zastanych przez badacza w terenie.

\section{Rezultaty badawcze}

Na pytanie o to, czy dzięki wspólnemu członkostwu w WOT badani nawiązali $\mathrm{z}$ innymi członkami organizacji relacje osobiste, nie tylko w postaci indywidualnej współpracy, ale także zaufania, lepszego dialogu, zrozumienia, transferu wiedzy itp., badani najczęściej deklarowali, że członkostwo w WOT nie ma wpływu na budowanie tego typu relacji. Potwierdzają to słowa różnych przedsiębiorców, w tym przedsiębiorcy reprezentującego obiekt noclegowy:

Badacz: „Czy może pan powiedzieć, że do któregoś z tych podmiotów z WOT-u wzrosło zaufanie dzięki członkostwu, przynależności do tej jednej organizacji?”.

Rozmówca: „(...) mam swój poziom kredytu zaufania i to zaufanie na pewno nie jest budowane gdzieś tam na impulsach z działalności takich organizacji, bo ona jest dość sucha (...). Tak że ja bym tutaj powiedział - OK, zaufanie jest i teraz nie wiadomo, czy... ale na pewno nie w wyniku współpracy [w ramach WOT] z może jakimś małym wyjątkiem".

O tym, że WOT na ogół nie działała jako organizacja stanowiąca płaszczyznę budowania współpracy dwustronnej, świadczył też fakt, że przedsiębiorcy często nie wiedzieli, iż inne, wymieniane przez badacza podmioty także są członkami WOT, lub niewiele wiedzieli o samej organizacji:

Badacz: „A współpracujecie z [nazwa podmiotu]?”.

Rozmówca: „O! To też, znamy się dobrze, a oni też są w WOC-ie?”.

Badacz: „Oni też są w WOC-ie”.

Rozmówca: „Ja nie wiedziałam nawet”. 
(...) Powiem tak, jeżeli chodzi o aktywność związaną z WOT-em - nie mam zielonego pojęcia. Kto z nich faktycznie... Wiem, kto jest szefem WOT-u i tak dalej - z którego tego punktu, to wiadomo. Natomiast jeżeli chodzi o to, jaką aktywność kto tam prowadzi w WOC-ie, no [to nie].

Wielu badanych podkreślało, że współpracuje z innymi przedsiębiorcami, w tym należącymi do WOT, ale nie wynika to raczej ze wspólnego członkostwa w tej organizacji. Potwierdzają to słowa dwóch właścicielek pensjonatów:

Korzystam z noclegów w willi [nazwa], czy korzystamy - nasi goście korzystają z basenu. No, to tak. Ale czy ja bym była w WOC-ie, czy nie, to pewnie ta współpraca by była.

Badacz: „A proszę mi powiedzieć czy gdyby nie było WOT-u, też byście Państwo z tymi podmiotami [współpracowali]?”.

Rozmówca: „No oczywiście, że tak, ja myślę, że WOT tu w tym momencie zupełnie nie ma żadnego znaczenia".

Wielu rozmówców porównywało WOT do innych organizacji partnerskich, do których należeli, podkreślając, że w przeciwieństwie do nich nie stanowi on na ogół organizacji służącej budowaniu dwustronnej współpracy biznesowej. Tak wypowiadała się właścicielka firmy transportowej na temat koła przewodnickiego oraz osoby należące do koła agroturystycznego „Agrogościna”, będące jednocześnie członkami WOT:

Rozmówca: „To jest tak samo, jak ja proszę Pani mam w kole przewodnickim. Tam mi nikt nie mówi, że ja muszę. Idę, bo uważam, że tak należy i tak trzeba, bo samo stowarzyszenie się, powiedzmy z tymi moimi kolegami, to jest rzecz pożądana. Że się znamy. My możemy się nie widzieć przez cały rok, ale potem w trakcie tego roku są sytuacje, kiedy ja potrzebuję na przykład kogoś na podmianę, to ja już wiem, że mogę zadzwonić tu czy tu. Prawda?".

Badacz: „A w WOC-ie to tak działa?”.

Rozmówca: „A w WOC-ie to to właśnie tak nie działa. Nie działa, dlatego, że wie Pani, ci ludzie są mało skonsolidowani ze sobą...".

Natomiast jako tako troszeczkę inaczej jest WOT postrzegany. Bo jak porównuję wszystko z agroturystyką, to u nas to wygląda tak, że to, że my to prowadzimy (...). Bo to nie chodzi o to, że się do agroturystyki zapisze masę ludzi, które będą bierne i siedziały, i będą przychodzić i będą mówić tak: ja zapłaciłam składkę tam 300 zł na rok i co teraz proszę nas rozliczyć (...). U nas pracuje zarząd i u nas pracują wszyscy i przez to my siebie poznajemy, przez to jest nam wszystko łatwiej ogarnąć niż w WOC-ie.

No właśnie, właśnie, bo oni [członkowie WOT] wątpię, żeby oni nas tak wspierali, jak my się wzajemnie wspieramy w Agrogościnie - agroturystyce, na pewno oni nie posyłają do nas ludzi, to na pewno nie, tylko my sobie wzajemnie. 
Rozmówcy twierdzili, że organizacja nie służy budowaniu współpracy dwustronnej, głównie dlatego, że jedynie niewielka część członków WOT spotyka się podczas zebrań czy imprez WOT, a to właśnie podczas tych spotkań można nawiązać bezpośredni kontakt:

Na przykład jeżeli członkowie się spotykają, to z tych 50 przyjdzie przykładowo 15 , tak? Czyli poza zarządem tam 5 osób więcej, tak? I to jest jedyny kontakt. Tak że trudno powiedzieć, że to jest kontakt, czy jakaś relacja, nie?

Jako przyczynę nieuczestniczenia w spotkaniach WOT najczęściej wskazywano brak czasu czy wiele obowiązków, co charakterystyczne jest zwłaszcza dla mikroprzedsiębiorstw stanowiących większość badanych:

To znaczy owszem, organizują takie imprezy integracyjne, ale my... nikt... nie uczestniczymy (...). Może źle, że jakoś za mało się integrujemy, ale to wynika z kwestii braku czasu.

Jednocześnie wielu rozmówców podkreślało, że mimo uczestniczenia w spotkaniach WOT relacje indywidualne $\mathrm{z}$ innymi podmiotami $\mathrm{z}$ tej organizacji budowali oni, opierając się nie na wspólnym członkostwie w WOT, ale na kontaktach prywatnych poza tą organizacją. Zdaniem badanych to właśnie one najbardziej służą nawiązywaniu dwustronnej współpracy biznesowej:

Powiem Pani, że na początku, jak zakładano Wiślańską Organizację Turystyczną, to przyznam się, że może myślałam o tym, że będziemy bardziej dostrzegani, ale właściwie po paru latach, powiem Pani, że kontakty, które były wcześniej, się najbardziej liczą.

Jeśli się znamy, to znamy się wcześniej, no i WOT jakby, no w tej kwestii niewiele nam tutaj [pomógł]...

Badania pokazały, że negatywna ocena WOT wynikała z faktu, iż przedsiębiorcy nierzadko nie wiedzieli, czego oczekiwać od organizacji, lub też mieli wobec niej oczekiwania niezgodne z celami, dla których WOT i inne tego typu podmioty są powoływane. Przykładowo, niektórzy oczekiwali od WOT bezpośredniego i silnego angażowania się w kwestie związane nie tylko z promocją turystyczną, ale także z inwestycjami infrastrukturalnymi czy z rozwiązywaniem różnego rodzaju problemów dotyczących rozwoju turystyki w Wiśle (głównie będących w gestii władz samorządowych, nie zaś organizacji takich jak WOT, w wielu wypadkach mogących odgrywać jedynie rolę opiniotwórczą czy doradczą):

Jest wiele w Wiśle, bardzo wiele spraw, którymi by się należało zająć, i jako organizacja turystyczna powinni się tym zająć, tymczasem oni tak jakby pewnych tematów nie zauważają. No kwestia powiedzmy dojazdów do Wisły, korków, ewentualnej obwodnicy. Powinni przecież dbać o to, żeby w przyszłości ci ludzie mieli możliwość dojazdu. 
Niespełnione oczekiwania, często wynikające z faktu, że były zbyt wygórowane, sprawiały, iż niektórzy przedsiębiorcy wycofywali się z członkostwa w WOT lub też po prostu przestawali się w tę organizację angażować:

(...) To jest trochę taka organizacja, że tak powiem, która za mało, za mało daje. O! Oni się dziwią, że ludzie im odchodzą i nie płacą składek, ale z kolei w prywatnej rozmowie takiej [mówią]: a po jaką cholerę? Co mi to da? Ja wiem, że to takie trochę samolubne podejście. Ja wiem, że turystyki się nie da kreować jedną osobą czy jednym pociągnięciem, że to trzeba jakoś, powiedzmy, robić globalnie, przynajmniej na terenie Wisły, wspólnie, no, ale takie mniej więcej jest podejście wielu ludzi. No, takie są odczucia.

Z kolei przedstawiciel jednej ze stacji narciarskich w Wiśle, mający doświadczenie jako uczestnik różnych form kooperacji, w taki sposób opisywał problemy związane ze zbyt wygórowanymi oczekiwaniami członków WOT w stosunku do tej organizacji:

Oni się spodziewają czegoś, czego WOT im nie da. Mnie doprowadza do szału takie podejście do tematu, kiedy przychodzi ktoś i pyta się, co miasto robi w jakichś tam sprawach. Owszem na wiele rzeczy miasto ma wpływ, ale na wiele rzeczy my mamy wpływ. I jeśli ja pójdę do burmistrza, to ja się z nim spotykam. Ale jak my pójdziemy w trzech, czterech z klastra, powiemy - burmistrzu, niepokoi nas sprawa mostku na potoku, który ma być remontowany, chcemy mieć więcej informacji. Chcemy mieć wpływ na to, kiedy będą rozpoczęte remonty, jak długo planowali organizację ruchu... I w tym momencie my jesteśmy już nie indywidualni. Tak że myślę, że tutaj jest pewne niezrozumienie. WOT nikomu nic nie da. On może stworzyć możliwości współpracy, ale to nie jest organizacja, która nam da pieniądze, która powie - słuchajcie, my za was coś załatwimy.

Jednocześnie rozmówcy podkreślali, że gdyby członkowie WOT dostrzegali bezpośrednie korzyści przynależności do tej organizacji, tak jak ma to miejsce w przypadku członków koła agroturystycznego „Agrogościna”, wówczas ocena WOT jako platformy budowania współpracy indywidualnej byłaby zdecydowanie lepsza:

(...) tylko, że myślę, że gdyby były korzyści wymierne w sensie dochodowości obiektów, które (...) przynależą do WOT-u, to na pewno większe zainteresowanie by było WOT-em...

Wielu rozmówców uważało, że organizacja podejmuje pewne wartościowe działania, np. w zakresie szkoleń czy promocji, jednak nie przekładają się one na rzeczywiste funkcjonowanie ich przedsiębiorstw:

Natomiast też wiele nie oczekuję, bo w zasadzie wszystko leży w gestii już samego czy kwaterodawcy, czy właściciela obiektu. A WOT z racji swojej organizacji rzeczywiście wychodzi naprzeciw i tam wysyła jakieś swoje propozycje, na które my $\mathrm{z}$ reguły przystajemy. Natomiast ja to personalnie nie kojarzę, bo to mi nie jest do niczego jakby potrzebne. 
Badania pokazały - co zresztą wprost deklarowała część rozmówców - że gdyby korzyści funkcjonowania WOT były łatwe do zidentyfikowania i bardziej wymierne czy namacalne, wówczas organizacja z pewnością byłaby lepiej oceniana:

Rozmówca: „Rzeczywiście jesteśmy we wspólnej reklamie, no to to jest niewątpliwie korzyść, jednak te materiały gdzieś tam wędrują na jakieś targi i tym podobne rzeczy, a w ogóle ktoś ma możliwość dowiedzenia się, że my w ogóle jesteśmy, prawda. Natomiast, wie Pani, jaka szeroka jest skala tego, że to się odbija w naszą stronę? - to naprawdę bardzo trudno to wiedzieć. Dlatego że, tak jak powiedziałam, że najczęściej jeżeli ktoś mnie w ogóle znajdzie, to mnie znajdzie przez reklamę w Internecie mojej własnej firmy".

Badacz: „I nie wiedzą Państwo w ogóle, na ile to z WOT-u wynika, że ktoś tam się... do Państwa zgłosił?".

Rozmówca: „Nie, nie”.

Część badanych podkreślała także, że aby WOT mógł lepiej funkcjonować, osoby zaangażowane w działalność organizacji powinny otrzymywać za nią wynagrodzenie:

W tej chwili mamy WOT - Wiślańską Organizację Turystyczną. Powiem tak, jest to fajne, aczkolwiek, jak każde stowarzyszenie dobrowolne i przerabialiśmy to w naszym branżowym stowarzyszeniu. I jeśli nie ma osoby, która dostaje pieniądze i jest rozliczana z pracy, to będzie taka współpraca bardzo... od akcji do akcji, od okazji do okazji - o, tak to nazwijmy.

Podobnie na ten temat wypowiadała się przedstawicielka Urzędu Miasta Wisła, będącego członkiem WOT:

(...) Też sobie zdaję sprawę z tego, że są organizacje, ale to są raczej regionalne organizacje, typu Śląska Organizacja, ROT-y, one mają większy budżet, one mają wsparcie $\mathrm{z}$ jednostek samorządowych większe, one mają przede wszystkim pracowników, one mają dyrektorów biur, którzy to wszystko prowadzą, a tu jest inna troszeczkę sytuacja: pracownik na pół etatu, i to jest za mało. Ale na więcej nie stać, po prostu, nie? Tak że chciałoby się więcej.

\section{Wnioski z badań}

Przeprowadzone badania pozwoliły stwierdzić, że Wiślańska Organizacja Turystyczna, mimo że w statucie jako jeden ze swoich celów wskazała, iż będzie stanowić platformę do nawiązywania kontaktów bezpośrednich oraz dwustronnej współpracy biznesowej między swoimi członkami, nie osiągnęła skutecznie tego celu. Nie tylko większość rozmówców uznawała, że jej istnienie nie stymuluje współpracy bilateralnej między członkami WOT, często wielu z nich nie wiedziało 
nawet, kto należy do WOT lub kto nią zarządza (tj. jaki jest skład zarządu). Udział niektórych badanych w organizacji sprowadzał się tylko do płacenia składek członkowskich, a czasem nawet, zgodnie z tym, co ustalono w rozmowie z sekretarzem WOT, nawet to było dla niektórych problemem. Jeśli rozmówcy twierdzili, że współpracują z innymi członkami WOT, większość z nich podkreślała, że kooperacja ta nie jest efektem wspólnego członkostwa w organizacji, lecz raczej osobistych kontaktów nawiązanych niezależnie od faktu członkostwa. Jednocześnie rozmówcy twierdzili, że możliwe jest, by organizacja stanowiła platformę poznania się jej członków i nawiązania między nimi bliższych relacji, w tym dwustronnej kooperacji biznesowej, na dowód podając, że inne organizacje, do których należą, np. koło przewodnickie czy agroturystyczne, skutecznie pełnią tę rolę.

Wskazywano też, że w przypadku WOT przyczynę braku skuteczności w osiąganiu tego celu może stanowić:

- duża liczba członków (w chwili prowadzenia badań było to 55 podmiotów, zaś wskazywane jako wzór koło „Agrogościna” zrzeszało około 20 podmiotów),

- duże zróżnicowanie (w tym różnorodność potrzeb i interesów) członków WOT,

- brak czasu przedsiębiorców turystycznych, którzy nie uczestniczą w spotkaniach organizacji, a przez to tracą szansę poznania się i budowania relacji dwustronnych.

Jako jedną z przyczyn wskazywano także brak wyraźnie dostrzegalnych, mierzalnych korzyści funkcjonowania WOT przy jednocześnie wyraźnych kosztach uczestnictwa w organizacji (składka członkowska). Przykładowo, wielu rozmówców uważało, że organizacja podejmuje pewne wartościowe działania, np. w zakresie szkoleń czy promocji w formie wydawanych katalogów, jednak nie przekładają się one na faktyczne funkcjonowanie ich przedsiębiorstw. Problem wynikał też z faktu, że jak pokazały badania, przedsiębiorcy często nie posiadali wiedzy na temat tego, czym zajmują się organizacje takie jak WOT, i mieli wobec niej zbyt duże, nieadekwatne do faktycznych celów oczekiwania. Jako jeden z problemów wymieniono także fakt, że osoby zaangażowane w działalność WOT powinny otrzymywać za to wynagrodzenie. Działanie członków zarządu na zasadzie pro publico bono zdaniem wielu badanych nie stymuluje przedsiębiorcy do prawdziwej aktywności i zaangażowania.

Przeprowadzone badania mają jednak pewne ograniczenia. Po pierwsze, wykorzystano metodę studium przypadku i zbadano tylko jedną lokalną organizację turystyczną, tj. WOT. Nie pozwala to na dokonanie uogólnień odnoszących się także do innych polskich LOT czy też innych organizacji partnerskich podobnego typu. Z pewnością wiele z nich stanowi lepszą płaszczyznę nawiązywania współpracy bilateralnej aniżeli objęta badaniem WOT. Po drugie, badania prowadzono w Wiśle - gminie dość specyficznej ze względu na wielkość, kulturę czy historię. 
Wyniki bez wątpienia zależą od wiślańskiego kontekstu, w którym badania były prowadzone. Po trzecie, większość wywiadów przeprowadzona została w okresie wakacyjnym (lipiec-sierpień 2013), kiedy przedsiębiorcy turystyczni dysponują ograniczonym czasem, co mogło przełożyć się na zakres zebranych informacji. Wreszcie, po czwarte, nie wszyscy członkowie WOT zgodzili się wziąć udział w badaniu (brak zgody 7 spośród 55 z nich). Zdaniem sekretarza WOT były to jednak podmioty w niewielkim stopniu zaangażowane lub w ogóle niezaangażowane w działalność organizacji, co pozwala uznać, że ich opinie nie wniosłyby wiele do dokonanych w badaniu ustaleń.

\section{Rekomendacje dla praktyki gospodarczej}

Zidentyfikowane przyczyny negatywnej oceny WOT jako platformy do budowania między członkami dwustronnych relacji biznesowych stanowią jednocześnie podpowiedź dla władz samorządowych oraz innych podmiotów zaangażowanych w powstawanie i rozwój tego typu organizacji, co warto zapewnić, by mogła ona także służyć stymulowaniu współpracy dwustronnej. Warto zatem zadbać o to, by mimo zróżnicowania członków organizacji podkreślać ich wspólne cele i wymierne korzyści, skuteczniej zachęcać do udziału w spotkaniach członków (np. w ramach walnego zgromadzenia czy innych okoliczności) - także przez organizowanie ich poza sezonem turystycznym, w okresie gdy przedsiębiorcy mają relatywnie więcej czasu i z większym prawdopodobieństwem mogliby w nich uczestniczyć. Konieczna jest także edukacja w zakresie tego, czym są organizacje partnerskie (w tym LOT i ROT) - do jakich celów są powoływane, co należy do ich kompetencji itp. Kluczowe jest także zapewnienie odpowiedniego finansowania tego typu organizacji (chodzi tu o gwarancję partycypowania samorządów lokalnych w kosztach ich funkcjonowania). W tym zakresie warto rozważyć na przykład zatrudnienie w organizacji stałych pracowników, którzy dzięki otrzymywanej pensji byliby w stanie mocniej zaangażować się w działanie tego typu struktur.

Podkreślić należy, że ci przedsiębiorcy, którzy stwierdzili, iż ich współpraca biznesowa z innymi członkami WOT była efektem wspólnego członkostwa w tej organizacji, byli wobec WOT dużo mniej krytyczni i sami wręcz podkreślali, że nie zdawali sobie na początku sprawy z tego, iż nawiązanie takiej dwustronnej kooperacji będzie dla nich większą korzyścią aniżeli korzyści, jakie zakładali, gdy przystępowali do organizacji. Istnienie takich relacji dwustronnych sprzyja zatem nie tylko pozytywnej ocenie organizacji jako całości (przykładem może być choćby przytaczane wcześniej koło agroturystyczne „Agrogościna”), ale także osiąganiu indywidualnych korzyści ekonomicznych przedsiębiorstw turystycznych 
zrzeszonych w strukturach partnerskich. To z kolei służy poprawie pozycji konkurencyjnej przedsiębiorstwa, a w perspektywie także całego obszaru.

\section{Literatura}

Achieving Competitive Advantage through Quality Management (2015), red. M. Peris-Ortiz, J. Álvarez-García, C. Rueda-Armengot, Springer.

Araujo L.M., Bramwell B. (2002), Partnership and Regional Tourism in Brazil, ,Annals of Tourism Research", vol. 29(4), https://doi.org/10.1016/s0160-7383(02)00033-6.

Augustyn M.M., Knowles T. (2000), Performance of Tourism Partnerships: A Focus on York, „Tourism Management”, vol. 21(4), https://doi.org/10.1016/s0261-5177(99)00068-0.

Bramwell B., Sharman A. (1999), Collaboration in Local Tourism Policymaking, ,Annals of Tourism Research", vol. 26(2), https://doi.org/10.1016/s0160-7383(98)00105-4.

Collaboration in Tourism Businesses and Destinations: A Handbook (2015), red. D. Gursoy, M. Saayman, M. Sotiriadis, Emerald Group Publishing.

Crotts J.C., Buhalis, D., March R. (2000), Global Alliances in Tourism and Hospitality Management, The Haworth Hospitality Press, An Imprint of The Haworth Press, New York-London-Oxford.

Czernek K. (2012). Uwarunkowania wspótpracy na rzecz rozwoju turystyki w regionie, Proksenia, Kraków.

Czernek K. (2017), Zakorzenienie społeczne jako determinanta wspótpracy w sektorze turystycznym, Wydawnictwo Uniwersytetu Ekonomicznego w Katowicach, Katowice.

Denzin N.K., Lincoln Y.S. (1994), Handbook of Qualitative Research, Sage Publications.

Eisenhardt K.M., Graebner M.E. (2007), Theory Building from Cases: Opportunities and Challenges, ,Academy of Management Journal”, vol. 50(1), https://doi.org/10.5465/ amj.2007.24160888.

Fedyk W., Morawski M. (2014), Regionalne organizacje turystyczne - organizacjami wspótpracy. Prawda czy fatsz, „,Folia Turistica”, vol. 32.

Granovetter M. (1985), Economic Action and Social Structure: The Problem of Embeddedness, „American Journal of Sociology”, vol. 91(3), https://doi.org/10.1086/228311.

Gray B., Wood D. (1991), Collaborative Alliances: Moving from Practice to Theory, ,Journal of Applied Behavioral Science", vol. 27(1), https://doi.org/10.1177/0021886391271001.

Harrigan K.R. (1988), Strategic Alliances and Partner Asymmetries (w:) Cooperative Strategies in International Business, red. F.J. Contractor, P. Lorange, Lexington Books, Lexington, MA.

Jack S., Dodd S.D., Anderson A.R. (2008), Change and the Development of Entrepreneurial Networks over Time: A Processual Perspective, ,Entrepreneurship and Regional Development", vol. 20(2), https://doi.org/10.1080/08985620701645027.

Jamal T., Getz D. (1999), Community Roundtables for Tourism-related Conflicts: The Dialectics of Consensus and Process Structure, „Journal of Sustainable Tourism”, vol. 7(3-4), https://doi.org/10.1080/09669589908667341.

Kostera M. (2003), Antropologia organizacji. Metodologia badań terenowych, Wydawnictwo Naukowe PWN, Warszawa.

Kozak M., Baloglu S. (2011), Managing and Marketing Tourist Destinations: Strategies to Gain a Competetive Edge, Routledge. 
March R., Wilkinson I. (2009), Conceptual Tools for Evaluating Tourism Partnerships, „Tourism Management”, vol. 30(3), https://doi.org/10.1016/j.tourman.2008.09.001.

Merinero-Rodríguez R., Pulido-Fernández J.I. (2016), Analysing Relationships in Tourism: A Review, „Tourism Management”, vol. 54, https://doi.org/10.1016/j.tourman.2015.10.010.

Miles M.B., Huberman A.M. (1994), Qualitative Data Analysis: An Expanded Sourcebook, Sage.

Pechlaner H., Volgger M., Herntrei M. (2012), Destination Management Organizations as Interface between Destination Governance and Corporate Governance, „Anatolia”, vol. 23(2), https://doi.org/10.1080/13032917.2011.652137.

Rahman N., Korn H.J. (2014), Alliance Longevity: Examining Relational and Operational Antecedents, „Long Range Planning”, vol. 47(5), https://oi.org/10.1016/ j.lrp.2012.05.003.

Rapacz A. (2005), Wspótpraca sektora publicznego i sektora prywatnego w miejscowościach i regionach turystycznych, „Prace Naukowe Akademii Ekonomicznej we Wrocławiu", nr 1074.

Siggelkow N. (2007), Persuasion with Case Studies, „Academy of Management Journal”, vol. 50(1), https://doi.org/10.5465/amj.2007.24160882.

Ustawa z dnia 25 czerwca 1999 r. o Polskiej Organizacji Turystycznej (2018), Dz.U. 2018, poz. 563.

\section{The Importance of Membership in Local Tourist Organisations for Building Bilateral Cooperation}

(Abstract)

One of the ways to compete for tourists is to create local tourist organisations in tourist areas. Their goal, apart from promoting tourism, is to create opportunities to establish bilateral economic cooperation between the entities associated in them. No research has been done to indicate whether affiliation in such organisations actually serves to build cooperation, how it builds cooperation or, alternatively, why it does not. This article seeks answers to these questions, and does so with the help of a case study on the Wisla Tourism Organisation (WOT) and semi-structured interviews conducted in 2013-2014 with 48 WOT members. The results of the research show that the WOT, to only a limited degree, enables the establishment of bilateral cooperation between members associated in this organisation. The reasons for this include the fact that the organisation's members have diversified needs and interests, largely fail to actively participate in WOT meetings, suffer from a lack of clearly perceptible, measurable benefits of participating in the organisation. At the same time, the organisation charges a membership fee. The article concludes with recommendations that could be used to change the situation.

Keywords: bilateral cooperation, partnership organisation, local tourist organisations, tourism. 